\title{
Transmedia Storytelling and Teaching Experience in Higher Education
}

\author{
Josefina Sánchez-Martínez ${ }^{1}$, Sergio Albaladejo-Ortega ${ }^{1}$ \\ ${ }^{1}$ Catholic University of Murcia, Murcia, Spain \\ Correspondence: Josefina Sánchez-Martínez, Catholic University of Murcia, Faculty of Social Sciences and \\ Communication, Murcia, Spain.
}

Received: March 5, 2018

Accepted: April 4, $2018 \quad$ Online Published: April 16, 2018

doi:10.11114/ijce.v1i1.3077

URL: https://doi.org/10.11114/ijce.v1i1.3077

\begin{abstract}
The present paper analyzes an innovative teaching experience, Transmedia Narrative, in the field of Higher Education. This experience based on the Project-Based Learning (PBL) method and collaborative processes, that has a solid constructivist framework, is proposed as a fertile ground for creative experimentation and the production of interesting pieces and exemplary transmediation strategies. The innovative teaching project was conducted between 2013 and 2017 at the Faculty of Communication, Catholic University of Murcia (Spain). Part of the results at this project were presented at the 'International Conference on Communication in the profession and the university of today: contents, research, innovation and teaching' (CUICIID) in 2014, in order to make the premier disclosure of preliminary data and test the design of the project. So far, the project created works in progress of immense professional and academic value. Results of this project are not only relevant, but also provide a significant and original contribution to the international literature related to contemporary education.
\end{abstract}

Keywords: PBL, higher education, innovation, transmedia storytelling, motivation

\section{Introduction}

In a society characterized by interactive and multidirectional flows of information enabled by the existence of new content distribution platforms, the use of traditional content in teaching experiences can lead to a decrease in motivation among higher education students. Likewise, students are also demotivated when they read scientific texts and feel that not only is their contribution to the work group unnecessary, but it is also unduly recognized. In a world that has increasingly become hyper-aware of media and transmedia, students have not only become producers and consumers ('prosumers') of leisure and entertainment products, but also of their own Personal Learning Environments (PLE) (Castañeda \& Adell, 2013). With this background, we propose a change in the educational paradigm to include innovative and creative processes in university classrooms.

This article presents an innovative teaching project which aims to improve the acquisition of transversal and disciplinary educational competencies among students using transmedia storytelling. Narration (telling of stories) forms the basis of being human and is a necessary symbolic process -as through the spatial metaphor (displacement) and the dramatic metaphor (conflict) - through which a person matures or learns to mature (González-Requena, 1968). Currently, transmedia narrative has not only allowed for stories to not end, but also for stories to spread in an infinite manner through different platforms or mediums (Jenkins, 2003; Scolari, 2013). This way, each person can contribute something new to the construction of the 'diegesis' of a tale. However, transmedia narrative needs a point of origin so as to expand. Literary text acts as a starting point for creating the transmedia universe. Although the starting point (a.k.a. the seed) can be any type of narration (a film, a videogame, a comic book, a television series, a theater piece, etc.), starting from literary work is ideal for two reasons. Firstly, a fictional universe unfolded through literary work, promotes a richer collective imagination of its' readers more than the audiovisual universe. It allows for an independent 'mise-en-scène', that has not been filtered through the another author's point of view. Secondly, literary work calls for critical and in-depth reading, and requires a detailed analysis of narrative texts from the perspective of narratology (Genette, 1989, 1997).

This study conducted through PBL aimed to develop a transmedia storytelling project, using a literary text as its genesis to boost motivations levels among $3^{\text {rd }}$ year students studying towards Degrees in Journalism, Audiovisual Communication and Advertising and Public Relations at the Catholic University of Murcia in Spain. This project also attempted to foster creative knowledge among these students and implementation of educational competencies acquired during the preceding two years of university studies. 
Although transmedia narrative is not a new phenomenon, eruption of new technological platforms and active use of media has elevated a once privileged method of storytelling (books, movies, tv shows, etc.) into a highly participative user experience. This shift in creative power has made transmedia narrative the focus of attention of many academics and researchers. Subsequent to this, various teaching experiences have emerged in the last few years in Spain (see: Andreu-Sánchez \& Martín-Pascual, 2014; Freitas \& Castro, 2010; Hernández, 1998; Martos-Núñez \& Martos-García, 2012; Peñalba-García, Pérez-Bowie, \& Noguerol-Jiménez, 2013; Suárez-Puerta, 2009). Most of them have incorporated multi-disciplinary theoretical frameworks (Grandío, 2016), media convergence (Jenkins, 2006), the concept of 'prosumer' (Jenkins, 2003; Toffler, 1981), etc. Examples of digital and transmedia literacy are found within these projects (Grandío, 2015; Kalogeras, 2014; Thomas et al., 2007). However, none of these studies planned the creation of a transmedia narrative project from the recreation of a literary text to a transmedia franchise. This concept, supported by Pratten (2011), implies that a book, which is no longer a single product to be independently consumed, can be transformed into a doorway that opens to a transmedia experience. Starting with the creation of new media pieces, each piece of information in the story can be completed, each action can be re-interpreted, expanded or recreated, and built up by critical contributions to enhance holistic knowledge of the piece.

\section{Theoretical Framework}

In 2003, Henry Jenkins defined transmedia narratives as specific forms of tales that are expanded through different systems of meaning (verbal, iconic, audiovisual, interactive, etc.) and media (cinema, comics, television, videogames, theater, etc.). Scolari (2013) described transmedia narratives as not simply an adaptation of one form of media into another (for example, a book into a film), but a strategy that goes beyond the original narrative work by encompassing a variety of media and languages. Transmedia narrative can be applied to any type of story: fictional, persuasive or informative. Transmedia narratives have been accorded a good reception in social contexts, and have been promoted by media convergence (Jenkins, 2006) and hypermediations (Scolari, 2008).

The theory of hypermediations explains how the media phenomenon are formed by "processes of exchange, symbolic production and consumption that are developed in an environment characterized by a large number of technologically interconnected subjects, media and languages" (Scolari, 2008, p. 115). In the past few years, different means of distribution, such as multiplatform, cross-media and transmedia, have become increasingly relevant. While multiplatform distribution disseminates the same product through a variety of platforms "without the content being altered, but adapted to different language-forms" (Guerrero-Pérez, 2011, p. 98), cross-media sequentially and chronologically resorts to various platforms in order to experience the whole story (Bechmann, 2006; Bjur et al., 2014; Davidson, 2010; Noguera et al., 2014; Schrøder, 2011). Although transmedia disperses different products using diverse media-types, each piece can stand-alone and be consumed in isolation (Jenkins, 2003).

What will the inclusion of transmedia storytelling among the learning tools in university education imply? Of importance, students will encounter an experience that is not foreign to them, as it already exists in society. Because transmedia narrative is dotted with greater interactive capacities and more complex multidirectional structures, resulting communication processes are more participative in nature and aligned to students' own preferences compared to traditional fictional products. Students may therefore feel more motivated to take up transmedia narratives as a challenge.

Transmedia provides infinite possibilities from a narrative point of view. The idea of being able to extend a story of a literary work through very different products can attract a heterogeneous public to the same work of fiction. Transmedia fiction therefore is able to reach its potential followers through various methods, favors closer and richer relationships between products and their consumers, which increase motivation and unleashes more consistent and active participation aligned to the interests and needs of each consumer.

In this context, it is important to mention the different expansion formulas of a story. To this effect, some of the different expansion strategies associated with seriality exist to expand a storyline. The 'prequel' is situated in the past of the original work's chronology. The 'interquel' is the content that explains events occurring between two temporal events in a story. The 'sequel' introduces events that unfold after the original narrative ends. Aside from extensions associated with seriality, the concept 'remake' is a new version of the same work, 'reboot' is a re-launch of a story that retains only the most important elements of the starting story but starts everything else, "crossover' is a "transmedia format where diegetic and/or stylistic features from two or more fictional worlds combine, resulting in a new cultural derived product" (Guerrero-Picó \& Scolari, 2016, p. 187), and 'spin-off' is a project that is born of a previous work usually by turning a secondary character into the protagonist of his/her own story.

Notably, the recreation of a literary work through other types of media not only relates to the traditional concept of adaptation, but is also associated with the recreation and expansion of the original world. Many authors have focused on only one of the principles of transmedia storytelling that states that "the content of the different elements that compose 
the transmedia narrative world cannot be repeated" (Guerrero-Picó \& Scolari, 2016, p. 186) and have placed the concept of adaptation outside the umbrella of transmedia narration (Aarseth, 2006; Hutcheon, 2012; Murray, 2012). Conversely, the school of thought backed by Jenkins (2006), Long (2007) and Mora (2014) considers translated adaptations as transmedia narrations. The adaptation of a literary work from one language to another does not necessarily correspond to its original work due to the suppressions, contractions and content additions made by the adapter and technical reasons associated to the 'mise-en-scène' (Dena, 2009; Scolari, Jiménez-Morales, \& Guerrero-Picó, 2012). Therefore, the adaptation should be considered as another form transmedia storytelling as long as it significantly supports the original narrative.

\section{Methods}

\subsection{Project Design}

Most innovative practices associated to PBL in Higher Education are based on the works of John Dewey (2010) and William Hart Kilpatrick (1918). The Project-Based method, a didactic alternative based on an epistemological constructivist theory, has both an individualizing and a social learning approach and is subsequently focused on a person, whose meaningful learning experience is enhanced (Blumenfeld et al., 1991). This project is based on a pragmatic philosophy, that states 'concepts are understood through observable consequences' and 'learning occurs due to direct contact with objects'. Students therefore become more conscious and responsible for their own learning when working with real professional projects (Zuniga \& Cooper, 2016), based on reflections of Harwell (1997), Coll (2000), Branda (2009), Deejring (2014, 2015), Balanescu (2015) and Kwanjai (2016).

The Project-Based method is categorized into 8 different phases (Project description, Information search, Design, Planning, Execution, Conclusion, Assessment and Dissemination) that were organized into seven two-hour work sessions (a.k.a. creative experimentation workshops) conducted over a period of 14 weeks, while sub-group meetings were held every two weeks.

Table 1. Production planning of transmedia project

\begin{tabular}{lll}
\hline Session & Activity & PBL step \\
\hline $\mathbf{1}$ & $\begin{array}{l}\text { Explanation of the transmedia narrative project by the professor: nature, dimension, } \\
\text { specific guidelines (premises) and set principles to follow (Decalogue+1) }\end{array}$ & $\begin{array}{l}\text { Project } \\
\text { inception }\end{array}$ \\
\hline $\mathbf{2}$ & $\begin{array}{l}\text { Presentation by each student of the piece devised -according to the information } \\
\text { searched- to the professor and the classmates }\end{array}$ & $\begin{array}{l}\text { Information } \\
\text { search }\end{array}$ \\
\hline $\mathbf{3}$ & $\begin{array}{l}\text { Design proposal for the piece based on the information previously collected. The } \\
\text { professor provides guidance and helps the student to plan the performance of his/her } \\
\text { work }\end{array}$ & $\begin{array}{l}\text { Design / } \\
\text { Planning }\end{array}$ \\
\hline $\mathbf{4}$ & $\begin{array}{l}\text { Materialization and exposition of the complete project in the classroom for receiving } \\
\text { corrections and suggestions }\end{array}$ & Execution \\
\hline $\mathbf{5}$ & $\begin{array}{l}\text { Presentation of the corrections made by the student and display preparation for the } \\
\text { Transmedia Creation Exhibition }\end{array}$ & Conclusion \\
\hline $\mathbf{6}$ & Simulation of showing and explanation of the final creation & Assessment \\
\hline $\mathbf{7}$ & Celebration of the exhibition & Dissemination \\
\hline
\end{tabular}

Source: Own elaboration

\subsection{Project Participants}

The PBL method was used to create an innovative teaching project that was implemented during four consecutive academic years $(2013-2014 ; 2014-2015 ; 2015-2016$; 2016-2017) within the core of the 'Aesthetics and Fiction in Communication' course that is part of the three degree programs at the Catholic University of Murcia in Spain: Journalism, Audiovisual Communication and Advertising and Public Relations.

Each year, the students from these three degrees were combined into two large groups (30 students each), and added up to 60 students. For the learning of this subject, each of these groups was divided into two working sub-groups. Therefore, in order to implement the innovative teaching project, they were grouped into four sub-groups, comprising of 15 individuals each. 
Table 2. Project participants

\begin{tabular}{|c|c|c|c|c|c|c|c|c|c|c|c|c|c|}
\hline & \multicolumn{6}{|c|}{ LARGE GROUP A } & \multicolumn{6}{|c|}{ LARGE GROUP B } & \multirow[b]{3}{*}{ Total } \\
\hline & \multicolumn{3}{|c|}{ Sub-group 1} & \multicolumn{3}{|c|}{ Sub-group 2} & \multicolumn{3}{|c|}{ Sub-group 3} & \multicolumn{3}{|c|}{ Sub-group 4} & \\
\hline & JOU & AUD & $\mathrm{A} / \mathrm{P}$ & JOU & AUD & $\mathrm{A} / \mathrm{P}$ & JOU & AUD & $\mathrm{A} / \mathrm{P}$ & JOU & AUD & $\mathrm{A} / \mathrm{P}$ & \\
\hline 2013-2014 & 6 & 5 & 4 & 7 & 4 & 4 & 4 & 6 & 5 & 4 & 5 & 6 & 60 \\
\hline 2014-2015 & 5 & 5 & 5 & 5 & 4 & 6 & 7 & 4 & 4 & 6 & 4 & 5 & 60 \\
\hline 2015-2016 & 7 & 5 & 3 & 6 & 6 & 3 & 4 & 5 & 6 & 4 & 6 & 5 & 60 \\
\hline 2016-2017 & 4 & 5 & 6 & 4 & 5 & 6 & 6 & 4 & 5 & 6 & 5 & 4 & 60 \\
\hline
\end{tabular}

Source: Own elaboration

\subsection{Project Literary Works}

To implement this project, a literary work was chosen for each academic year. For the years' 2013-2014, 2014-2015, 2015-2016 and 2016-2017, the following were selected: the novel The Oxford Crimes. Murder as the riddle (2003) by the Argentinian writer Guillermo Martínez, the literary text Solaris (1961) from the Polish author Stanisłav Lem, the work World War Z: An Oral History of the Zombie War (2006) by the American author Max Brooks, and the work 1984 (2007) by Georges Orwell, respectively.

\subsection{Project Inception}

During the first session, the nature and dimension of the transmedia narrative project were explained. Students were reminded about transmedia narrative because they were already familiar with the concept from previous courses since the book Transmedia Narratives. When every medium counts by Scolari (2013) had been used before in the course 'Technology III: Interactive multimedia' during that same academic year. However, their knowledge on the subject was reinforced with by reading other documents that took on a project design hands-on approach, such as Creator's Guide to Transmedia Storytelling: How to Captivate and Engage Audiences across Multiple Platforms by Phillips (2013) and The producer's guide to Transmedia: How to Develop, Fund, Produce and Distribute Compelling Stories Across Multiple Platforms by Bernardo (2011). Nevertheless, the readings were not mandatory for the development of the project, but they could be used as reference materials.

During the initial meeting, specific guidelines to implement the project were provided (Table 3).

Table 3. Specific premises for transmedia project

\begin{tabular}{|c|c|c|}
\hline & Premise & Description \\
\hline 1 & Individual work & $\begin{array}{l}\text { Each piece had to have a unique value within itself, and at the same time } \\
\text { contribute to the group's work }\end{array}$ \\
\hline 2 & Constructivist approach & $\begin{array}{l}\text { This took advantage of all the knowledge acquired in the preceding five } \\
\text { semesters }\end{array}$ \\
\hline 3 & Full attendance of classes & $\begin{array}{l}\text { The classes that became truly creative and professional workshops through } \\
\text { collaborative work, allowed each student to incorporate the suggestions } \\
\text { provided by their professor as well as fellow students }\end{array}$ \\
\hline 4 & $\begin{array}{l}\text { Reading works of fiction that } \\
\text { served as the starting point of } \\
\text { the transmedia project }\end{array}$ & $\begin{array}{l}\text { Consequent to the different types of information that the novels offered, and } \\
\text { especially the potential gaps presented in each narrative, the possibility of } \\
\text { answering these voids would lead to new questions, so that the tales could be } \\
\text { extended for as long as the students wanted them to }\end{array}$ \\
\hline 5 & To do 'the best they can do' & $\begin{array}{l}\text { The student had to leave his or her mark recorded in each piece he or she } \\
\text { designed, aligned to his or her personal tastes, his or her professional } \\
\text { interests, and his or her academic competencies }\end{array}$ \\
\hline 6 & $\begin{array}{l}\text { Need of following the } \\
\text { so-called 'Decalogue }+1 \text {, }\end{array}$ & $\begin{array}{l}\text { With the support of the teaching staff, each extension piece had to be aligned } \\
\text { to these principles }\end{array}$ \\
\hline
\end{tabular}

\section{Source: Own elaboration}

Throughout the following six meeting sessions, and having the premises in mind at all times, the students started to move forward with the design and development of their creations, guided by the teaching staff during the entire process, from the original idea to the final product. 


\subsection{Information Search}

During information search, students would read the work and then complement it with social and cultural context inquiries. This included a detailed analysis of the narrative to identify possible sources of information and setting coordinates based on the coherence of the narrative universe where which the characters could move about. The student would then decide among different possibilities for transmedia extension that would be accorded by the work, the most appropriate format to house their creation and make the final decision on how to structure the discourse.

\subsection{Individual Student Project Design}

Although each student was free to decide what piece he or she wanted to create and how he or she would create it, every project would follow a set principles (Decalogue+1) that were extracted and adapted from Jenkins (2009), Gomez (2007) and Davidson (2010) (Table 4).

Table 4. Decalogue+1 for transmedia project

\begin{tabular}{|c|c|c|}
\hline & Principle & Description \\
\hline 1 & Expansion of the story & $\begin{array}{l}\text { Each piece developed should contribute to the narrative, offering } \\
\text { new storylines, contributing new data to those that already exist in } \\
\text { the novel, and even including new arguments starting with the } \\
\text { elements that shape the original work of fiction }\end{array}$ \\
\hline 2 & Coherence between pieces & $\begin{array}{l}\text { It is necessary that the different contributions created respect the } \\
\text { original novel at all times, being respectful of all the events, } \\
\text { characters, locations and objects presented within it }\end{array}$ \\
\hline 3 & Re-interpretation of the starting text & $\begin{array}{l}\text { The numerous situations that are described in the novel are } \\
\text { interpreted in a specific manner that answers to the logic that rules } \\
\text { over the development and the conclusion of the tale }\end{array}$ \\
\hline 4 & $\begin{array}{l}\text { Multiplicity in the approach to the } \\
\text { events and characters }\end{array}$ & $\begin{array}{l}\text { The aim of this strategy is to offer new points of view (other than } \\
\text { the original ones) through pieces that, as they are created by } \\
\text { authors, gather their own and differentiated vision }\end{array}$ \\
\hline 5 & Extraction of fictional elements & $\begin{array}{l}\text { The value of making something that is imaginary 'real' allows a } \\
\text { reader to extend the story and broadening the transmedia experience }\end{array}$ \\
\hline 6 & Induction of new ideas and values & $\begin{array}{l}\text { It is possible to introduce more abstract elements that are equally } \\
\text { interesting: ideas and values }\end{array}$ \\
\hline 7 & Recreation of events only mentioned & $\begin{array}{l}\text { Taking into account this void, new fictional pieces can re-create } \\
\text { these events with great liberty as far as the form and, overall, the } \\
\text { content are concerned, creating an important contribution to the } \\
\text { original text }\end{array}$ \\
\hline 8 & $\begin{array}{l}\text { Treatment of the information from the } \\
\text { storyworld }\end{array}$ & $\begin{array}{l}\text { The possibility of creating an informative product that could only } \\
\text { exist in the fictional universe or storyworld }\end{array}$ \\
\hline 9 & Advertising and promotional strategies & $\begin{array}{l}\text { Creating pieces with a promotional nature, not of the novel itself, } \\
\text { but also of products, places or events that are mentioned within it }\end{array}$ \\
\hline 10 & Self-contained pieces & $\begin{array}{l}\text { Regardless that the creations nourish themselves from the original } \\
\text { novel, or support it by extending their narrative, it is important that } \\
\text { each of these pieces are able to be consumed independently }\end{array}$ \\
\hline 11 & Valuable contribution of each product & Each piece is able to contribute something new \\
\hline
\end{tabular}

Source: Own elaboration from the contributions by Jenkins (2009), Gomez (2007) and Davidson (2010)

\subsection{Planning and Execution}

Given the personal and independent nature of this project, and depending the piece chosen by each student, planning each story would therefore require different work rhythms and structures. Accordingly, the professors provided guidance during the decision-making process and helped manage the time used to construct each story. During the execution phase, each student developed his/her piece, utilizing the production planning that was decided in the previous phase (Table 1).

\subsection{Conclusion of the Project}

Once the pieces were created, students showcased each of the works to their professors and all the members of their workgroup. This was done to receive suggestions for improvement and possible corrections. This phase was very important, as it made known for the first time a professionally-planned product, which would receive constructive 
critique to enable it advance. The arguments received served to improve the piece and prepare it for its ensuing presentation in an event of greater academic impact.

\subsection{Assessment and Dissemination}

Pieces were disseminated to the scientific and professional society in three ways. Firstly, through a web page created to house all its contents, which would make them freely accessible. Secondly, through an academic event entitled 'Transmedia Creation Exhibition', organized according to disciplines and moderated by professors from different areas of knowledge from the Faculty of Communication of the Catholic University of Murcia, for students to present their creations as professional pitches. And lastly, information about the event and the pieces was shared through social networks -mainly Twitter and Instagram- and mass media.

\section{Results}

The results of the teaching innovation project, developed during four academic years, were as follows.

\subsection{The First Academic Year 2013-2014}

In the $1^{\text {st }}$ year of the project (2013-2014), the story The Oxford Crimes. Murder as the riddle was used. The experience led to the creation of 60 unique and different extension pieces in diverse formats: reports, trailers, scripts for shorts, radio soap operas, blogs or games, among others. The Audiovisual Communications students created 19 pieces, the Journalism students prepared 25 transmedia stories, and the Advertising and Public Relations students designed 16 pieces (Table 5). During this year, the transmedia creation exhibition was not celebrated, but the impact was assessed through a specific event: the author of one of the pieces (a newly invented story) contacted the creator of the starting literary work -the very own author Guillermo Martínez- to have him become a participant in the transmedia creation project.

Table 5. The Oxford Crimes. Transmedia pieces 2013-2014

\begin{tabular}{llllll}
\hline Audiovisual Communication & Number & Journalism & Number & Advertising and Public Relations & Number \\
\hline Scripts for shorts & 4 & Written news items & 6 & Event organizations & 5 \\
Comics & 3 & Stories & 5 & Blogs & 4 \\
Board games & 3 & Print newspapers & 3 & Web pages & 3 \\
Trailers & 2 & Micro-stories & 2 & Radio commercials & 2 \\
Webpages & 2 & Diaries & 2 & Tourist routes & 1 \\
Scripts for webseries & 2 & Memories books & 1 & Scripts for tv spots & 1 \\
Scripts for TV pilots & 1 & Biographical profiles & 1 & & \\
Voice memo diaries & 1 & Press interviews & 1 & & \\
Radio soap operas & 1 & Radio programs & 1 & & \\
& & Radio columns & 1 & & \\
& & Radio tourist routes & 1 & & \\
Total & & Twitter accounts & 1 & & \\
\hline
\end{tabular}

Source: Own elaboration

\subsection{The Second Academic Year 2014-2015}

The literary work Solaris was used in this year and works generated were shared on a webpage that was created as a platform to house 60 works that resulted from this experiment (Note 1). Likewise, a video of the teaching innovative project was disseminated through the social networks (Note 2). This year, the '1st Exhibition of Transmedia Creation: Solaris' organized a round 7 work sessions that was incepted and celebrated at the conference hall of the Catholic University of Murcia on the $10^{\text {th }}$ of June 2015. 
Table 6. Solaris. Transmedia pieces 2014-2015

\begin{tabular}{|c|c|c|c|}
\hline Session & Description & Pieces created & Total number \\
\hline \multirow[t]{6}{*}{ Session 1} & \multirow{6}{*}{$\begin{array}{l}\text { Audiovisual fiction as a paradigm of the extension } \\
\text { of the events in Solaris }\end{array}$} & Shorts & 3 \\
\hline & & Trailers & 3 \\
\hline & & Videogames & 2 \\
\hline & & $\begin{array}{l}\text { Interviews to directors of fake } \\
\text { documentaries }\end{array}$ & 1 \\
\hline & & Television advertising spots & 1 \\
\hline & & Total & 10 \\
\hline \multirow[t]{3}{*}{ Session 2} & \multirow{3}{*}{$\begin{array}{l}\text { The use of technology for providing the Solaris } \\
\text { experience }\end{array}$} & Webpages & 5 \\
\hline & & Apps & 4 \\
\hline & & Total & 9 \\
\hline \multirow[t]{5}{*}{ Session 3} & \multirow{5}{*}{$\begin{array}{l}\text { Communication media as a mirror of what is 'real' } \\
\text { in Solaris }\end{array}$} & Newspapers & 3 \\
\hline & & Reports & 2 \\
\hline & & Television news bits & 2 \\
\hline & & Reality shows & 2 \\
\hline & & Total & 9 \\
\hline \multirow[t]{4}{*}{ Session 4} & \multirow{4}{*}{$\begin{array}{l}\text { The presence of the radio in the recreation of } \\
\text { Solaris }\end{array}$} & Radio shows & 3 \\
\hline & & Radio news & 3 \\
\hline & & Radio soap operas & 3 \\
\hline & & Total & 9 \\
\hline \multirow[t]{5}{*}{ Session 5} & \multirow[t]{5}{*}{ The network in Solaris storytelling } & Blogs & 4 \\
\hline & & Wikipedia articles & 2 \\
\hline & & Twitter accounts & 1 \\
\hline & & Instagram accounts & 1 \\
\hline & & Total & 8 \\
\hline \multirow[t]{7}{*}{ Session 6} & \multirow{7}{*}{$\begin{array}{l}\text { Forms of dissemination in the Solaris setting: a sea } \\
\text { of books }\end{array}$} & Research Diaries & 3 \\
\hline & & Books of poems with illustrations & 1 \\
\hline & & $\begin{array}{l}\text { Books containing commented } \\
\text { illustrations }\end{array}$ & 1 \\
\hline & & Recipe books & 1 \\
\hline & & Perfumed books & 1 \\
\hline & & Short stories for children & 1 \\
\hline & & Total & 8 \\
\hline \multirow[t]{6}{*}{ Session 7} & \multirow{6}{*}{$\begin{array}{l}\text { The forms of dissemination in the Solaris setting: } \\
\text { science, art and advertising }\end{array}$} & Scientific conferences & 3 \\
\hline & & Photography projects & 1 \\
\hline & & Psychology projects & 1 \\
\hline & & Amusement parks & 1 \\
\hline & & Video blogs & 1 \\
\hline & & Total & 7 \\
\hline
\end{tabular}

Source: Own elaboration

\subsection{The $3^{\text {rd }}$ Academic Year 2015-2016}

This year, the literary text World War Z: An Oral History of the Zombie War was used as the starting point, a webpage was created (Note 3) and the second transmedia forum named ' 2 nd Exhibition of Transmedia Creation: World War Z' was held. It was on the 27th of May 2016 at the Catholic University of Murcia, where 60 works organized around seven sessions were presented. 
Table 7. Word War Z. Transmedia pieces 2015-2016

\begin{tabular}{|c|c|c|c|}
\hline Session & Description & Pieces created & Total number \\
\hline \multirow[t]{11}{*}{ Session 1} & The physical creation of advertising products & Zombie-repelling sprays & 1 \\
\hline & & Town models & 1 \\
\hline & & Survival kits & 1 \\
\hline & & Swords & 1 \\
\hline & & Dolls & 1 \\
\hline & & Fanpops & 1 \\
\hline & & Board games & 1 \\
\hline & & Paintings & 1 \\
\hline & & Videogame case covers & 1 \\
\hline & & Merchandising products & 1 \\
\hline & & Total & 10 \\
\hline \multirow[t]{7}{*}{ Session 2} & Organization of events as catalyzers of disconcert & Apps within a webpage & 1 \\
\hline & & Scavenger hunts & 2 \\
\hline & & Amusement parks & 1 \\
\hline & & Cellphone apps & 1 \\
\hline & & Campaigns for recycling zombies & 1 \\
\hline & & Fan events & 2 \\
\hline & & Total & 8 \\
\hline \multirow[t]{6}{*}{ Session 3} & Written press as a metaphor for survival & Research reports & 3 \\
\hline & & Printed newspaper front pages & 1 \\
\hline & & Front pages of digital newspapers & 1 \\
\hline & & Printed reports & 1 \\
\hline & & Survival magazines & 1 \\
\hline & & Total & 7 \\
\hline \multirow[t]{6}{*}{ Session 4} & The sound recreation of the $\mathrm{Z}$ universe & Radio psychology counseling offices & 1 \\
\hline & & Stories including radio soap operas & 1 \\
\hline & & Daily radio news programs & 2 \\
\hline & & Radio news programs & 2 \\
\hline & & Entertainment radio programs & 1 \\
\hline & & Total & 7 \\
\hline \multirow[t]{6}{*}{ Session 5} & The visual element as a parody of freedom I & Short films & 2 \\
\hline & & Trailers for short films & 2 \\
\hline & & Video blogs & 1 \\
\hline & & Corporate videos & 1 \\
\hline & & Fake documentaries & 1 \\
\hline & & Total & 7 \\
\hline \multirow[t]{5}{*}{ Session 6} & The visual element as a parody of freedom II & Teleshopping videos & 2 \\
\hline & & Television programs & 2 \\
\hline & & Youtube videos & 1 \\
\hline & & Television reports & 1 \\
\hline & & Total & 6 \\
\hline \multirow[t]{5}{*}{ Session 7} & Time and the survivability of the story & Diaries & 6 \\
\hline & & Short stories & 5 \\
\hline & & Literary scripts & 4 \\
\hline & & Total & 15 \\
\hline & & & 60 \\
\hline
\end{tabular}

Source: Own elaboration

\subsection{The $4^{\text {th }}$ Academic Year 2016-2017}

This year, the 1984 novel was used as a gateway to the transmedia experience. Created material was displayed on a web page (Note 4) and 60 transmedia pieces organized by specific themes were exhibited at the third transmedia forum entitled ' $3{ }^{\text {nd }}$ Exhibition of Transmedia Creation: 1984', held at the same University on the $22^{\text {nd }}$ of May 2017. 
Table 8. 1984. Transmedia pieces 2016-2017

\begin{tabular}{|c|c|c|c|}
\hline Session & Description & Pieces created & Total number \\
\hline \multirow[t]{6}{*}{ Session 1} & \multirow{6}{*}{$\begin{array}{l}\text { The creation of advertising products: } \\
\text { entertainment, contemplation and } \\
\text { dissemination }\end{array}$} & Comics & 3 \\
\hline & & Paintings & 3 \\
\hline & & Trading card games & 1 \\
\hline & & Board games & 2 \\
\hline & & Merchandising products & 3 \\
\hline & & Total & 12 \\
\hline \multirow[t]{2}{*}{ Session 2} & \multirow{2}{*}{$\begin{array}{l}\text { The organization of events as a formula } \\
\text { for personal liberation }\end{array}$} & Amusement parks & 4 \\
\hline & & Total & 4 \\
\hline \multirow[t]{2}{*}{ Session 3} & \multirow{2}{*}{$\begin{array}{l}\text { The nonsense of the dissemination of } \\
\text { information content }\end{array}$} & Newspapers & 8 \\
\hline & & Total & 8 \\
\hline \multirow[t]{2}{*}{ Session 4} & \multirow{2}{*}{$\begin{array}{l}\text { The still image and the expression of } \\
\text { emotional }\end{array}$} & Catalogues of photographs & 9 \\
\hline & & Total & 9 \\
\hline \multirow[t]{2}{*}{ Session 5} & \multirow{2}{*}{$\begin{array}{l}\text { The manipulation of thought through } \\
\text { sound }\end{array}$} & Radio shows & 7 \\
\hline & & Total & 7 \\
\hline \multirow[t]{3}{*}{ Session 6} & \multirow{3}{*}{$\begin{array}{l}\text { The metamorphosis of the audiovisual in } \\
\text { a directed universe }\end{array}$} & Short videos & 8 \\
\hline & & Documentaries & 2 \\
\hline & & Total & 10 \\
\hline \multirow[t]{2}{*}{ Session 7} & The written word as a defense & Short stories books & 10 \\
\hline & mechanism and refuge of the story & Total & 10 \\
\hline
\end{tabular}

Source: Own elaboration

\section{Discussion}

By implementing a transmedia narrative project to foster students' creative spirit, this project aimed to develop an effective teaching experience to aide in reigniting and increasing students' motivation. This method, that relies on previously acquired educational competencies, has its genesis in literary text. Its objective was to counteract the reduced motivation resulting from current traditional linear non-interactive teaching-learning experiences.

This project, that had to be implemented over the course of 4 years, motivated all students to participate each year in creating pieces are of professional and transmedia value under the guidance and advice of both their professors and colleagues. This motivation could be attributed to the first premise that required each student to shape his or her own creation. This promoted personal autonomy and gain contemporary transmedial flow skills. This motivation could also be attributed to the fifth premise that encouraged students to excel in what they do. By this they were able to fuel their personal and professional skills, increase their self-esteem and reaffirm their own creative capacities.

By adhering to the Decalogue+1, through expansion and need for coherence, students were able to enhance their abilities to determine what aspects ought to be respected so as not to violate fundamental laws that govern the original work of fiction. In this sense, the Decalogue+1 became essential for students, serving not just as a guide, but also helping them to reflect on the relevance of their decisions when creating a true transmedia product. In addition, the professors observed that throughout the different phases of the project, students connected transmedia strategies with skills from previous courses seeking to create products able to respond to their own interests as consumers.

The re-interpretation of the starting text, the multiplicity in the approach to events and characters, and the extraction of fictional elements and induction of new ideas and values, activates an ability to connect knowledge and assumptions from the fictional world with those of the real world. This can lead to new perspectives and practices which increase the students' interest dynamics of the academic environment. The recreation of events mentioned in the text and its informational or promotional treatment encourages students to relate storytelling to information and marketing strategies critical to conglomerates that make up the media ecosystem. Since students have to create self-contained pieces, this promotes the implementation of proficiencies of the so-called prosumers, consumers who make their own contributions to a social fabric. To be prosumers, students must be able to conceptualize others' ideas so as to manifest their own.

Throughout the course of study, students created pieces that satisfied predetermined premises and principles, demonstrate their comprehension of the mechanics applied, and made a distinctive and valuable contribution to the whole literal work and the obtained academic and professional capacities relevant to the $21^{\text {st }}$ century.

This study also developed a methodology that could be implemented in other universities in other countries which could be consolidated in the learning curricula of each academic year as an original, creative and sustainable academic model. 


\section{References}

Aarseth, E. (2006). The culture and business of cross-media productions. Popular communication, 4(3), 203-211. https://doi.org/10.1177/1354856517700555

Andreu-Sánchez, C., \& Martín-Pascual, M. A. (2014). El Transmedia Audiovisual en el aula universitaria. Communication Papers, 4, 69-76. Retrieved from http://ojs.udg.edu/index.php/CommunicationPapers/article/view/108/CeliaAndreu_MiguelAngelMartin

Balanescu, R. (2015). The Project-Based Learning in the Higher Education. Theoretical and practical aspects. In Proceedings Of The Scientific Conference AFASES, (pp. 1159-1164). Brasov, Romania: AFASES. Retrieved from http://www.afahc.ro/ro/afases/2015/afases_2015/socio/Balanescu\%20Ra-mona.pdf

Bechmann, A. (2006). Internet and cross media productions: Case studies in two major Danish media organisations. Australian Journal of Emerging Technologies and Society, 4(2), 94-107. Retrieved from http://apo.org.au/system/files/15351/apo-nid15351-100326.pdf

Bernardo, N. (2011). How to Develop, Fund, Produce and Distribute Compelling Stories Across Multiple Platforms. Lisboa: beActive.

Bjur, J., Schrøder, C., Hasenbrink, U., Courtois, C., Adoni, H., \& Nossek, H. (2014). Cross-media use. Complexities in contemporary audiencehood. In N. Carpentier, K. Schrøder, \& L. Hallett (Eds.), Audience transformations. Shifting audience positions in late modernity (pp. 15-29). New York: Routledge.

Blumenfeld, P. C., Soloway, E., Marx, R. W., Krajcik, J. S., Guzdial, M., \& Palincsar, A. (1991). Motivating project-based learning: Sustaining the doing, supporting the learning. Educational Psychologist, 26(3\&4), 369-398. https://doi.org/10.1080/00461520.1991.9653139

Branda, L. A. (2009). El aprendizaje basado en los problemas. ¿Un inicio del aprendizaje a lo largo de la vida? DPM. Avances en Desarrollo Profesional Continuo en Medicina, 2(4), 15-21. Retrieved from https://egavilan.files.wordpress.com/2010/05/branda-abp-un-inicio-del-aprendizaje-a-lo-largo-de-la-vida.pdf

Castañeda, L., \& Adell, J. (eds.). (2013). Entornos personales de aprendizaje: claves para el ecosistema educativo en red. Alcoy: Marfil.

Coll, C. (2000). El constructivismo en el aula. Barcelona: Graó.

Davidson, D. (2010). Cross-media Communications: An introduction to the Art of Creating Integrated Media Experiences. Pittsburgh: ETC Press.

Deejring, K. (2014). The design of web-based learning model using collaborative learning techniques and a scaffolding system to enhance learners' competency in higher education. In Procedia - Social and Behavioral Sciences, (pp. 436-441). https://doi.org/10.1016/j.sbspro.2014.01.236

Deejring, K. (2015). The validation of web-based learning using collaborative learning techniques and a scaffolding system to enhance learners' competency in higher education. In Procedia - Social and Behavioral Sciences, (pp. 34-42). https://doi.org/10.1016/j.sbspro.2015.01.623

Dena, C. (2009). Transmedia Practice: Theorising the Practice of Expressing a Fictional World across Distinct Media and Environments (Doctoral dissertation). University of Sydney, Sydney, Australia. Retreived from http://www.christydena.com/phd/

Dewey, J. (2010). Experiencia y educación. Madrid: Biblioteca Nueva.

Freitas, C., \& Castro, C. (2010). Narrativas audiovisuales y tecnologías interactivas. Revista Estudios Culturales, (5), 19-42. Retrieved from http://servicio.bc.uc.edu.ve/multidisciplinarias/estudios_culturales/

Genette, G. (1989). Palimpsestos. La literatura en segundo grado. Madrid: Taurus.

Genette, G. (1997). Paratexts: Thresholds of interpretation. New York: Cambridge University Press. https://doi.org/10.1017/CBO9780511549373

Gomez, J. (2007, October 2). Producers Guild of America New Media Council (PGA-NMC). Retrieved from http://www.pganmc.blogspot.com.es/2007/10/pga-member-jeff-gomez-left-assembled.html

González-Requena, J. (1968). El discurso televisivo: espectáculo de la postmodernidad. Madrid: Cátedra.

Grandío, M. (2015). Indicadores para la evaluación de la alfabetización transmedia en los estudios universitarios de Comunicación. Cuadernos Artesanos de Comunicación, 77, 35-40. https://doi.org/10.4185/cac77

Grandío, M. (2016). El transmedia en la enseñanza universitaria. Análisis de las asignaturas de educación mediática en 
España (2012-2013). Palabra Clave, 19(1), 85-104. https://doi.org/10.5294/pacla.2016.1-9.1.4

Guerrero-Pérez, E. (2011). El ecosistema multiplataforma de los grupos televisivos españoles: los formatos de entretenimiento. Revista Comunicación y Hombre, 7, 85-103. Retrieved from http://www.redalyc.org/ articulo.oa?id=129420882005

Guerrero-Picó, M., \& Scolari, C. (2016). Narrativas transmedia y contenidos generados por los usuarios: el caso de los crossovers. Cuadernos.Info, 38, 183-200. https://doi.org/10.7764/cdi.38.760

Harwell, S. (1997). Project-based learning. In W.E. Blank \& S. Harwell (Eds.), Promising practices for connecting high school to the real world (pp. 23-28). Florida: University of South Florida.

Hernández, F. (1998). Repensar la función de la Escuela desde los proyectos de trabajo. Pátio. Revista Pedagógica, 6, 26-31. Retrieved from http://www.oei.es/historico/br25.htm

Hutcheon, L. (2012). A theory of adaptation. New York: Routledge.

Jenkins, H. (2003). Transmedia Storytelling. Moving characters from books to films to video games can make them stronger and more compelling. Technology Review (on line). https://doi.org/10.4236/ce.2016.77105

Jenkins, H. (2006). Convergence culture: Where old and new media collide. New York: New York University Press.

Jenkins, H. (2009, December 12). Revenge of the Origami Unicorn: The Remaining Four Principles of Transmedia Storytelling Retrieved from http://henryjenkins.org/2009/12/revenge_of_the_origa-mi_unicorn.html \#sthash.VqJ KbTbi.dpuf

Jenkins, H. (2009, December 12). The Revenge of the Origami Unicorn: Seven Principles of Transmedia Storytelling (Well, Two Actually. Five More on Friday). Retrieved from http://henryjenkins.org/2009/12/the_revenge_of_the_origami_uni.html\#sthash.q3gdIqyi.dpuf

Kalogeras, S. (2014). Transmedia storytelling and the new era of media convergence in Higher Education. London: Palgrave MacMillan. https://doi.org/10.1057/9781137388377

Kilpatrick, W. H. (1918). The project method. The Use of the Purposeful Act in the Educative Process. New York: Teachers College Bulletin.

Kwanjai, D. (2016). The design of Knowledge management to develop creative thinking for higher education with project base learning. In Proceedings Of The Multidisciplinary Academic Conference (pp. 63-70). Prague, Czech Republic: Czech Technical University. Retrieved from http://www.2016.erpacongress.com/complete-proceedings.pdf

Long, G. (2007). Transmedia Storytelling. Business, Aesthetics and Production at the Jim Henson Company. Massachusetts: MIT Press.

Martos-Núñez, E., \& Martos-García, A. (2012). Lecturas fantásticas y Transliteracidad. Profissão Docente, 12(26), 71-98. Retrieved from http://www.revistas.uniube.br/index.php/rpd/article/view/561

Mora, V. L. (2014). Approach to the terminological problem of transmedia narrativity. Caracteres. Estudios culturales $y$ críticos de la esfera digital, 3(1), 11-40. Retrieved from

http://revistacaracteres.net/wp-content/uploads/2014/05/Caracteresvol3n1mayo2014-problema-term-inologico-tran smedia.pdf

Murray, S. (2012). The adaptation industry: The cultural economy of contemporary literary adaptation. New York: Routledge.

Noguera, J., Martínez, J., Nicolás, M., Pérez, M., Gómez, A., Grandío, M., Hernández, F., \& Lasheras, P. (2014). Economía de la participación. Madrid: Fundación EOI.

Peñalba-García, M., Pérez-Bowie, J. A., \& Noguerol-Jiménez, F. (2013). Intermedialidad e intertextualidad en la narrativa gráfica. In Memorias de Innovación Docente (pp. 150-176). Salamanca, España: Universidad de Salamanca. Retrieved from https://gredos.usal.es/ jspui/bitstream/10366/122551/1/MID_12_037.pdf

Phillips, A. (2013). Creator's Guide to Transmedia Storytelling: How to Captivate and Engage Audiences across Multiple Platforms. New York: McGraw-Hill.

Pratten, R. (2011). Getting Started With Transmedia Storytelling: A Practical Guide for Beginners. CreateSpace: Amazon.

Schrøder, K. (2011). Audiences are inherently cross-media: Audience studies and the cross-media challenge. Communication Management Quarterly, 18(6), 5-28. https://doi.org/10.1515/bsmr-2017-0012 
Scolari, C. (2008). Hipermediaciones: elementos para una teoría de la comunicación digital interactiva. Barcelona: Gedisa.

Scolari, C. (2013). Narrativas Transmedia. Cuando todos los medios cuentan. Barcelona: Deusto.

Scolari, C., Jiménez-Morales, M., \& Guerrero-Picó, M. (2012). Narrativas transmediáticas en España: cuatro ficciones en busca de un destino cross-media. Comunicación y Sociedad, 25(1), 137-163. Retrieved from https://www.unav.es/fcom/communication-society/es/articulo.php?art_id=409

Suárez-Puerta, B. L. (2009). Reflexiones sobre la enseñanza en situaciones transmediales. Investigación y Reflexión, 17(2), 183-198. Retrieved from http://www.redalyc.org/articulo.oa?id=90913042010>

Thomas, S., Joseph, C., Laccetti, J., Mason, B., Mills, S., Perril, S., \& Pullinger, K. (2007). Transliteracy: crossing divides. First Monday, 12(12). http://dx.doi.org/10.5210/fm.v12i12.2060.

Toffler, A. (1981). La tercera ola. Bogotá: Plaza \& Janés.

Zuniga, A., \& Cooper, T. M. (2016). Project-Based Learning: 7 Ways to Make It Work. Educational Leadership, 73(9), 72-76. Retrieved from

http://www.ascd.org/publications/educational_leadership/jun16/vol73/num09/ProjectBased_Learning@_7_Ways_t o_Make_It_Work.aspx

\section{Notes}

Note 1. Website from the 1st Exhibition of Transmedia Creation: Solaris. Available at: http://ljpalao.wix.com/solaris

Note 2. The making of video can be watched in the following YouTube link: http://youtu.be/ a0WT7wXPazk

Note 3. The creations derived from the World War $Z$ literary work are accessible from the following website: https://creatransworldz.wordpress.com/

Note. 4 The creations derived from the 1984 literary work are accessible from the following website: https://creatransmedia1984.wordpress.com/

\section{Copyrights}

Copyright for this article is retained by the author(s), with first publication rights granted to the journal.

This is an open-access article distributed under the terms and conditions of the Creative Commons Attribution license which permits unrestricted use, distribution, and reproduction in any medium, provided the original work is properly cited. 